\title{
Investment priorities of modern development of agrarian factories Zakarpattia
}

\section{Spaskyi G. ${ }^{1}$, Havrylova A. ${ }^{2}$}

1, 2Zakarpatska state agricultural experimental station of NAAS, Svobody avenue, 17, Velyka Bakta, Beregovskyi region Zakarpatska oblast, Ukraine; e-mail: ${ }^{1}$ gszpassky@kmf.uz.ua

The purpose. To determine investment priorities of modern development of agrarian factories of Zakarpattia. Formation of offers for building congenial investment climate as important competitive advantage of the further economic and innovative development. Methods. Monographic, calculated, mathematical-statistical. Results. Effective investment secures fast response of agrarian factories on influence of factors of external and inner spaces. Skilful use of different sources of investment, unlocking of crediting of agrarian factories, development of investment climate, inadmissibility of mass bankruptcies, solution of structural and social problems, saving of own and overgrowth of innovative potential of development and investment appeal - are the basic priorities of development of agrarian factories of the oblast. Conclusions. Mainstreams in solution of problems of development of village terrains of Zakarpattia are radical changes, concerning administrative-territorial control. It will promote implementation of all opportunities and resources of village terrains of boundary region in social development, as well as structure of village land-use.

Key words: investment priorities, agrarian factories of Zakarpattia, priority trends in development of agriculture, sources of investment, specialization.

\section{https://doi.org/10.31073/agrovisnyk201806-11}

Setting of a problem. Nowadays, for the Transcarpathian agrarian sector, the had occurred an immediate need in the innovative and informational technologies investment, in resource, technical program provision, prior development of the food markets and infrastructure, as in these questions the agrarian sector considerably falls behind from the industry.

The development of the region's agrarian sector of economics is impossible without the real investing, increasing and filling the basic capital, restructuration of all the financial-investment sphere and creation of the suitable investment climate.

Competitiveness of the agrarian production in the regions of Ukraine depends on its investment. Investments are necessary for the agrarian enterprises for the transformation to the stable household activity, for the re-equipment of production, and for the improvement of the production quality.

Economic science prognoses the results of investment sphere transformation, grounds the priority directions of the agrarian enterprises' investment activity.

Analysis of the latest investigations and publications. The scientific works of the home scientistseconomists Sharp U., Alexander G., Beili D., [5], M.Y. Demianenko [7], M.F. Kropyvko [3], S.M. Kvasha [8], Y.O. Lupenko [3], M.J. Malika [3], Marmul M.O. [4], H.M. Pidlisetzkiy [6], V.Y. Mesel-Veselyaka [10], Samuelson P.A.[11] and others, are dedicated to the elaboration of the scientific backgrounds for the investment into the agrarian sector of economics. However, not all the questions of this sphere have been completely solved.

The experience of the developed countries shows, that none of the countries had reached the considerable results without the involvement of the costs of the home and foreign private investors. For the enterprises the investments mean the modernization and technical re-equipment. Introducing the energy and resource preserving technologies, and thus, decrease of the part of material spending in the structure of prime cost and work pay hike, production of competitive production. For the economics in general it means 
the market saturation with the high quality production, growing of the cumulative demand, increase of the consumer spending, revenue side of the gross domestic product. [5].

Improvement of the investment climate and increase of the level of material-technical provision of agrarian sector is a considerable problem. In agriculture during the years of independence there hadn't been provided the expanded reproduction of the main capital, and continually grew its consumption. That's why the necessary condition for the increase of the volumes of agricultural production, creation of the favorable conditions for the realization of a complex of works in the plant production is the increase of the volumes of investments and growing the productive potential of the enterprise. [6].

M.Y. Demianenko touches upon the question of the legacy of income forming at the expense of the free financial resources attraction into the ownership of the enterprise, through the mechanism of the state support of the agrarian enterprises. [7].

Aim of the article -to define the investment priorities of the modern development of Transcarpathian agrarian enterprises. Tracing the favorable investment climate as an important competitive advantage of the further economic and innovative development.

Exposition of the basic results of investigation. Agriculture of Transcarpathia is being in the crises state now. Stagnant processes are conditioned by the reasons of the long term character. The main of them are the low profitability and unprofitability of production of the separate basic types of agrarian production, absence of the state support of the farmer households, unprofitable cooperatives, lowered prices on the agrarian production, absence of the market and social infrastructure. Material-technical bases, which had been composed for today in agriculture, social infrastructure of the village rapidly, degrade. The problems of the social-economic activation of the lowland, mountainous and pre mountainous territories of the region are not being solved.

Under such circumstances the effectiveness of the use of the land resources remains rather low.

The yield capacity of the main agricultural crops is several times lower, than in the developed countries. The agrarian production does not correspond to the international demands of quality and safety, as $92,4 \%$ of agrarian production is being produced by the private households of population, which are limited by the material, financial, technological and informational resources. The insufficient attention is being paid to the land conservation from the destructive influence of the natural and anthropogenic character. The result of degradation of the agrarian lands is the low level of their productivity. The production of the gross production of agriculture in the calculation on 1 ha of the agrarian lands in Transcarpathia during the last years made up in average 426 Euro, while in the EU countries- more than 2 th.Euro [9].

Solving all these problems and further development of Transcarpathian agriculture are in the creation of the conditions, under which the competitiveness of the branch will increase, various functions of agriculture will further develop, which will contribute to the most full population employment, the optimal agro landscapes will be created, rationally used the land resources, the environment will be preserved.

The structure of agrarian sector of the region includes more than 1700 subjects of household activity, namely more than 1400 farmer households, approximately 220 business partnerships, more than 80 enterprises of other forms of activity.

Agriculture of the region makes up almost $18 \%$ of gross value added of the region provides with the raw materials the food industry branch. The share of the region in the general volume of gross production makes up $1,7 \%$.

Priority directions of the agrarian sector development of the region's economics are the production of potatoes, grain (cereal) crops, grain legumes, vegetables, fruits, grapes, raspberries, tobacco, sunflower, milk, cattle meat, sheep meat and wool, pork and so on. 


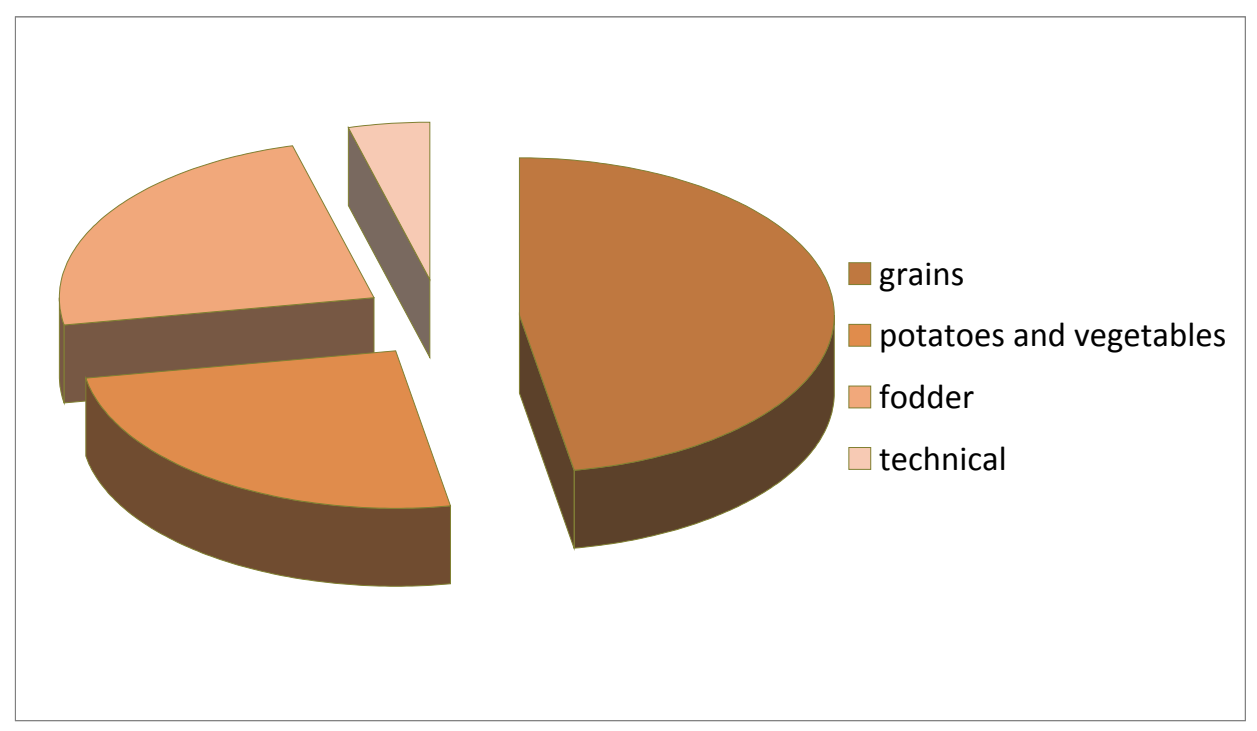

Pict. 1 Structure of the crop acreages of Transcarpathia

Transformation to the stable economic growth is possible after the increase of the investments into agriculture of the territory under investigation, improvement of its investment-innovative provision.

Effective investment guarantees the fast reaction of the agrarian enterprises on the influence of the factors of outer and inner environment. The skillful use of the different sources of investment, unblocking of the agrarian enterprises credit provision, improvement of the investment climate, prevention of the mass bankruptcy, solving the structural and social problems, preserving their own and growing the innovative potential of development and investment attractiveness- are the main priorities of the region's agrarian enterprises development.

By means of investigations, there had been set, that on the contemporary stage for the investment activity of Transcarpathian agrarian enterprises the following features are characteristic: low level of cooperation between the gross value added, provided by the enterprises of the branch and investments into agriculture, insufficient influence of the realized investments on the increase of agricultural production, delay of the volumes of investments from the tempo of gaining the basic means in the enterprises of agrarian sector of economics.

According to the theory, the gross added value is the main source of costs for realization of investments, the part of which has to make up to $20 \%$ of its volume.

In the Transcarpathian agrarian enterprises the dynamics of the corresponding correlation during 2005 2015 is very unbalanced (table.1).

\section{Dynamics of gross added value and investments into agriculture of Transcarpathia}

\begin{tabular}{|l|l|l|l|l|l|l|l|l|l|l|l|}
\hline Indicator & \multicolumn{7}{|c|}{ Year } \\
\cline { 2 - 10 } & 2005 & 2006 & 2007 & 2008 & 2009 & 2010 & 2011 & 2012 & 2013 & 2014 & 2015 \\
\hline $\begin{array}{l}\text { Gross added value of agraria } \\
\text { enterprise (in the factual price } \\
\text { 2010)n in in mIn hrn }\end{array}$ & 1088 & 1268 & 1360 & 1636 & 1656 & 11667 & 13436 & 15410 & 15830 & 17748 & 15795 \\
\hline $\begin{array}{l}\text { Investments into the basic ca } \\
\text { of agriculture (in factual price } \\
\text { 2010) mln hrn }\end{array}$ & 18,1 & 24,2 & 48.5 & 39,4 & 57,1 & 46,7 & 44,7 & 45,8 & 46,7 & 41,2 & 65,5 \\
\hline $\begin{array}{l}\text { Gross production of agricultul } \\
\text { the comparative prices of of 2 }\end{array}$ & 3665,4 & 3739,3 & 3755,1 & 3766.7 & 3788,9 & 3838,3 & 3998,9 & 4207,3 & 4312,9 & 4308.3 & 4095,9 \\
\hline
\end{tabular}

Source: Statistic yearly annual of Transcarpathia over 2015. Statistics headquarters in Transcarpathia. Uzhgorod 2016. 
So, in 2005 the part of investments in the enterprises of the agrarian sector in the gross added value of agriculture made up $1,7 \%$, y $2010-0,4$, a y $2015 p$.- $4,1 \%$.

This means, that the considerable growth of the part of investments in the gross added value of the household concerns only the short term period. To our minds, this can be conditioned by the necessity of renewing of the material-technical bases against the separate economic stabilization of agrarian production. Alongside with this, non-correspondence of the dynamics of investments and gross added value proves the carefulness of the owners as to its realization.

The tendency of breaking down between the realized investments and increase of production of agrarian goods is being shown during 2005-2015. This shows the comparison of the indicators of agrarian production and investments into the agrarian sector of the region. Investments into agriculture had increased from 18,1 $\mathrm{mln} \mathrm{hrn} \mathrm{in} 2005$ to $65,5 \mathrm{mln}$ hrn in 2015, this is in 3,6 times(table. 1). The agrarian production had increased from $3665,4 \mathrm{mln}$ hrn to $4095,9 \mathrm{mln}$ hrn correspondingly, this makes up $111,7 \%$.

The investigations had proved that the reasons of such non correspondence are the unfavorable conjuncture of the international markets, which didn't provide the advanced recoupment of investments into the means of production, and the influence of the currency exchange rate, which could negatively influence the indicators of the volume of real investments. Besides, their role plays the investment conditions, which still limit the motivation for investment activity of the small enterprises.

There should also be mentioned, that the level of agrarian production growth should be viewed as the main indicator of efficiency of innovative-investment activity in the agrarian enterprises of the region. Increase of investments exceeds the increase of the gross production more than in 3,5 times.

The determining direction of the agrarian enterprises development is the essential increase of their efficiency and strengthening the financial-investment state. What concerns the farmer households, here there is being observed not as much the growth of their quality, as the increase of the areas of land use at the expense of the rent or buying them.

It is reasonable to maximally use the present possibilities for the development of the organic agriculture. It is important to foresee giving the state support for its introduction, provide the spending compensation on the certification conducting, analysis, control, to help in the promotion of organic production to the markets.

The development of the agriculture in the region should be realized in the following directions:

- lowland zone - production of grains, potato, vegetables, fruits, grapes, meat and dairy cattle farming, swine rearing;

- piedmont zone- production of grains, potatoes, meat and dairy cattle farming;

- mountainous zone- sheep breeding, meat and dairy cattle farming. Economically profitably is to grow potato, raspberry and fodder.

The peculiarities of the mountainous territories allow to form the own model of functioning of the organic agrarian enterprises, basing on the private authentic genesis technologies of the animal production, which differ from the traditional ones. There are favorable conditions for the production of the ecologically safe and clean meat and dairy products and preserving the genetic fund of the Carpathian Mountains sheep breed, and of brown Carpathian breed of cattle.

In spite of the fact, that in the households of population the main part of products is being produced, the corresponding storage-selling network is absent. The present storage subdivisions of the recycling enterprises do not correspond the contemporary needs, do not provide the conditions of. That's why in the bases of the market infrastructure building up, there should be the creation in the rural area of the service providing cooperatives. Formation of the network of the fruit-vegetable, diary, meat, service and other unions of small goods producers will contribute to the creation of the additional working places and employment of the population.

In is possible to transfer to the stable economic growth by means of increasing the investments into agriculture of the area under investigation, improvement of its investment-innovative provision. 
Among the reasons of investment unattractiveness there could be singled out the slow tempo of reforming the regional economics, imperfect legislative basis, and irrational division of the inner investments: private and state, high taxes, excessive regulation and hot-buttoned economics of the region.

Nowadays the economics of the region is influenced by the complicated European and home economic processes. Capital outflow, growing distrust to the banking system, credit provision reduction - all these facts negatively influence the development of all the types of economic activity and correspondingly lowered the demand on the production.

The problem of investment activity functioning in the agrarian enterprises differs by the peculiarity of its complicated and multifaceted character, as it unites the interests of all the business entities. [2].

Competitiveness of the agrarian production in any region of Ukraine depends on its investment activity. Investment is necessary for the enterprises for transformation to the stable household activity, for the reequipment of the production, and for improvement of the quality of production. Investments are an important source of forming the financial-credit resources of the country, liquidation of the local disproportions. [3].

An important feature of the efficiency of the investment work is the investment activity. The investment activity of the agrarian enterprises is being introduced into its active, aim-oriented and result giving activity as to introducing the investments from all the inner and outer sources, and also the efficient use of the involved investment resources. Especially topical for the agrarian enterprises is the problem of choice and search of the sources of investments. [4].

In the process of investigation of the Transcarpathian agrarian enterprises' investment activity efficiency we have singled out four types of the agrarian entities' specialization. According to the calculations, the biggest relative share $(50,7 \%)$ in the general amount of agrarian enterprises have the formations, which are specialized on the production of grains, fruits, grapes and grain and meat.

Investments into the agrarian enterprises of each specialization type are shown in the table2.

\section{Investments in Transcarpathian region agrarian enterprises of different types of specialization} on the end of 2015 (in average per one enterprise).

\begin{tabular}{|c|c|c|c|c|c|c|}
\hline \multirow[b]{2}{*}{$\begin{array}{r}\text { Type of } \\
\text { specialization }\end{array}$} & \multicolumn{3}{|c|}{ Investments } & \multirow{2}{*}{$\begin{array}{l}\text { Income per } 1 \\
\text { of agrarian lar } \\
\text { th hrn }\end{array}$} & \multirow{2}{*}{$\begin{array}{l}\text { Level of } \\
\text { profitability of } \\
\text { main activity } \\
\%\end{array}$} & \multirow{2}{*}{$\begin{array}{l}\text { Level of } \\
\text { profitability of } \\
\text { investments } \\
\text {, } \%\end{array}$} \\
\hline & $\begin{array}{l}\text { Per } 1 \\
\text { Enterprise, th.hr }\end{array}$ & $\begin{array}{l}\text { Per } 1 \\
\text { agricultural } \\
\text { hrn c- } 5\end{array}$ & $\begin{array}{l}\text { Per } 1 \text { agraria } \\
\text { worker, hrn }\end{array}$ & & & \\
\hline Grain & 469,6 & 214,3 & 1,6 & 173,4 & 10,2 & 80,9 \\
\hline Grain-meat & 922,3 & 358,0 & 5,8 & 77,8 & 3,7 & 21,7 \\
\hline Fruit & 715,7 & 164.7 & 5,4 & 267,6 & 16,2 & 91,3 \\
\hline Grape & 1474,1 & 599,6 & 6,3 & 397,5 & 16,9 & 66,3 \\
\hline
\end{tabular}

Source: Own calculations.

As we see, the major part of investments per 1 ha of agricultural lands invested the enterprises, which belong to the grape and grain-meat type of specialization,, correspondingly 599,6 and 358,0 hrn, which concerns the enterprises of other types, the amount of investments is much lower.

For the further development of the region's agrarian enterprises it is necessary to constantly realize the monitoring of changes and make the corresponding corrections. Firstly, it is necessary to renew trust of the investors and population, to conduct proper activity of the banks and enterprises, which is going to be the guarantee for providing the stability of the credit and investment markets. It is also necessary to regulate the economic relations in the state in such a way, that they would provide the equal exchange between agriculture and other spheres of economics. 
Taking into consideration the traditions and nature-climate conditions, the development of the agrarian production should be realized in the following directions: production of potatoes, high quality grains, vegetable growing, horticulture and farm gardening, viticulture, meat and dairy cattle farming, swine farming, sheep breeding, poultry breeding, amimal farming, pedigree work, selection, seed studies. Increase of yield capacity will be reached through the new agrarian technologies, deepening of the selection-breeding work, biological promotion concentration of production specialization and development of cooperation. This will allow to provide the stopping of the decline, stabilization and growing the volumes of agrarian production, and thus will contribute to the more full provision with the foodstaff of both- local population and a big group of the tourists.

In the agrarian enterprises the investment should be concentrated on the introduction of the highly productive innovations, bio and nanotechnologies, establishing of the production of the effective chemical products for protection of the plants and animals, modernization and re-equipment of the production, using the innovative technologies. The direct state investments are of great importance for the provision of the realization of priorities of development by means of selection and seed farming support, breeding work in animal farming, environmental protection.

In the conditions of the limitation of the home financial resources solving the problem of the sufficient financing of the scientific-technical and innovative activity demands the search of the perspective resources of financing, among which are the creation of the venture funds through the effective introduction of the costs of the corporative sector of economics with the corresponding state guarantees for the financial provision of the scientific-technical and innovative activity; using the banking credit provision and foreign investments. [8].

Reestablishment of the credit provision can be provided in the case, if it will be accompanied by the serious measures for the further stabilization and rehabilitation of the whole financial-economic system. Besides, when adopting the credit provision policy, it is necessary to establish the optimal sizes of the credit interest rate, to regulate the question of the bail, risks insurance of the agrarian and other borrowers, to improve the procedure of giving credits and reconsider the list of the corresponding documents.

It is proposed to reestablish the marketing activity of the agrarian enterprises, where we have to assess, compare and choose the effective channels of production sale and providing the services. To practice different variants of development, to use factoring, forward contracts, exchange trade, auctions, increase the export to Europe.

From the point of view of management, it is necessary to view the alternatives of development and choose the optimal strategies basing on the deeper analysis of the agrarian enterprises activity in the conditions of the operative cycles change, outer and inner environment, skillfully management, the current assets and liquidity, storage, transport on the logistic schemes and on the bases of IT to direct the innovative activity on the creation, mastering, production and expansion of the principally new types of production on the bases of introducing the bio and resources preserving technologies, contribute to the improvement of the social development and ecologic environment, to grow the export capital. [10].

In order to use various sources of investment, it is necessary to realize the accumulation and rationalization of the use of the introduced and private costs when selecting the priorities of development, wider implement the leading home and foreign experience of forming the investment sites and potential. For the investment sites in practice it is rational to carve out financial property assets, being: land plots, objects of unfinished buildings, free productive powers, integral property complexes, and other objects, which are given to the investor on the treaty bases for realization of the investment or innovative project. In the current year the investments had increased on 59,0\% comparing with the previous year. Such changes are conditioned by the capital inflow, increase on $9,1 \mathrm{mln}$ hrn of the foreign investments. However, banking credit provision does not stimulate the agrarian production of the region. 


\section{Conclusions}

The main directions of solving the problems of the rural territories of Transcarpathia development are the radical changes, which will touch upon the administrative-territorial management and establishment. This will contribute to the realization of all the possibilities and resources of the rural areas of the near border region in the social development; improvement of the structure of the rural lands use.

Involving the outer and mobilization of the inner investments, renewing of trust of the investors and population are possible under the condition, that most of the Ukrainian banks will strengthen the capitalization, that there will be realized a more balanced activity of agrarian enterprises, which is going to become a guarantee for the provision of the stability and normalization of the credit and investment markets.

Forming the favorable investment climate in the market economics is taking place both - on the macro and regional levels by means of assessment of the existing problems, searching the ways of improving the situation and further optimization of the complex of political, legal, economic, social, organizational, informational, branch and regionally specific factors.

\section{Bibliography}

1. Sharp U., Aleksander G., Bejli D. (1997). Investicii. [Investments]. Moskva: INFA-M,. 485 p. [in Russian].

2. Havryliuk O.M. [2008]. Investytsiinyi imidzh ta investytsiina pryvablyvist Ukrainy. [Investment image and investment attractiveness of Ukraine]. Finansy Ukrainy. № 3. P. 79 - 93. [in Ukrainian].

3. Demianenko M.la. (2008). Finansovi chynnyky formuvannia dokhodiv u silskomu hospodarstvi. [Financial factors for income generation in agriculture]. Ekonomika APK. № 5. P. 18-20. [in Ukrainian].

4. Kvasha S.M. (2000). Zovnishnoekonomichna diialnist APK Ukrainy: stan, stratehiia i taktyka. [Foreign Economic Activity of Ukrainian Agribusiness: Status, Strategy and Tactics]. Kyiv: ZAT «NIChLAVA»,. 252 p. [in Ukrainian].

5. Marmul L.O. (2008). Osnovni pryntsypy ta osoblyvosti formuvannia investytsiinoi diialnosti $v$ ahrarnii sferi ekonomiky. [Basic principles and peculiarities of formation of investment activity in the agrarian sector of the economy]. Materialy mizhnar. nauk.-prakt. konf. Kyiv: RVPS Ukrainy NAN Ukrainy. 2. P. $288-289$. [in Ukrainian].

6. Lupenko Yu.O., Kropyvko M.F., Malika M.I. et al. (Eds). (2013). Pidvyshchennia konkurentospromozhnosti ta sotsialnoi spriamovanosti ahropromyslovoho vyrobnytstva na osnovi rozvytku klasternykh system. [Increasing the competitiveness and social orientation of agro-industrial production on the basis of the development of cluster systems]. Kyiv: NNTs «IAE»,.40 p. [in Ukrainian].

7. Pidlisetskyi H.M. (2007). Ekonomichni problemy vidtvorennia osnovnoho kapitalu ahrarnoho sektoru. Finansovi problemy formuvannia i rozvytku ahrarnoho rynku. [Economic problems of reproduction of capital assets of the agrarian sector]. Kyiv: NNTs «IAE». P. 158 - 163. [in Ukrainian].

8. Lupenko Yu.O. Mesel-Veseliak V.la. (Eds). (2012). Stratehichni napriamy rozvytku silskoho hospodarstva Ukrainy na period do 2020 roku; 2 vydannia, pereroblene i dopovnene. [Strategic directions of development of agriculture of Ukraine for the period till 2020]. Kyiv: NNTs «IAE». $218 p$. [in Ukrainian].

9. Statystychnyi shchorichnyk Zakarpattia, 2015. [Statistical Yearbook of Zakarpattya, 2015]. (2016). Holovne upravlinnia statystyky u Zakarpatskii oblasti. Uzhhorod. 546 p. [in Ukrainian].

10. Tkachuk V.A., Kulhanyk O.M. (2008). Kontseptualni zasady formuvannia sotsialnoi sfery silskykh terytorii. [Conceptual basis for the formation of the social sphere of rural areas]. Naukovyi visn. Odeskoho DEU. № 3(59). P. 49 - 61. [in Ukrainian].

11. Ficher P. (1999). Foring direct investment and goverments. New York. P. 134-136. [in Ukrainian]. 